\title{
Cultural Conflicts of the East and the West in Pearl Buck's Novels on China
}

\author{
Ling'e Shu \\ School of Foreign Languages \\ Jianghan University \\ Wuhan, China, 430056
}

\begin{abstract}
As the first American woman writer to win the Nobel Prize in Literature, Pearl Buck is indeed one of the earliest writers who are dedicated to the communication between the East and the West in early 20th Century. She lives both in the world of her American missionary parents and the world of a continually fascinating Orient, China. Therefore, Pearl Buck has deep affection for China and the Chinese people and thus sets China as the subject matter in most of her writings. The thesis is endeavored to explore Buck's cultural conflicts of the East and the West embodied in her novels by analyzing some of her novels focusing on China and Chinese people, consisting of cultural shock and cultural confrontation between the East and the West.
\end{abstract}

Keywords-Pearl S. Buck; cultural conflict; cultural shock; cultural confrontation

\section{INTRODUCTION}

Pearl Buck is the famous American writer in the $20^{\text {th }}$ century. She was born in America but was brought up in China, where she has lived for more than 30 years. She lives in two worlds, the world of her American missionary parents and the world of a continually fascinating Orient. She has created about 70 works including East Wind: West Wind, The Good Earth, Dragon Seed, Pavilion of Women and so on. In 1938, she became the third American but the first American woman writer to win the Nobel Prize in Literature, following Sinclair Lewis and Eugene O'Neill, "for her rich and truly epic descriptions of peasant life in China and for her biographical masterpieces". Pearl Buck is a prolific author and she has deep affection for China and the Chinese people and makes China as the subject matter in most of her writings. Furthermore, one of her consistent themes of her novels is the conflict and confluence between the East and the West. For example, her first novel East Wind: West Wind (1930) deals with the differences between Chinese traditions and American culture and their effects on each other. Her autobiography My Several Worlds (1954) tells her own stories as an outsider in the conflict between East and West, and portrays herself as a product of the confluence of the Eastern and Western cultures. Pearl Buck, being a daughter of missionary parents and having lived in China for the first half of her life, has felt deeply the conflicts between the Western culture and the Chinese culture.
Nowadays, human beings are entering a period when people of different cultures should learn to live and communicate peacefully and they should study mutual history, ideals, art and cultures. Otherwise, there must be misunderstandings, tensions, conflicts and disasters in this over-crowded world. (Huntington, 1987: 169)However, it is the truth that intercultural communication is inherently difficult between those people with different cultural backgrounds. And it will be more difficult when there are pre-instilled prejudices against each other. The sociologist Macionis has offered a detailed definition of prejudice while explaining its damaging effect on intercultural communication: "Prejudice amounts to a rigid and irrational generalization about a category of people. Prejudice is irrational to the extent that people hold inflexible attitudes supported by little or no direct evidence. Prejudice may target people of a particular social class, sex, sexual orientation, age, political affiliation, race or ethnicity." So when the East encounters the West, the cultural conflicts will inevitably happen to them.

\section{WEAK CONFLICT: CULTURE SHOCK}

The term culture shock was first introduced in the 1960's by Dr. Kalervo Oberg, an American anthropologist. Culture Shock is initiated by the deep anxiety that results from losing unfamiliar signs or symbols of social intercourse. (Oberg, 1960: 176) It can be described as the feeling of confusion and disorientation that one experiences when faced with a large number of new and unfamiliar people and situations. People's responses to culture shock vary greatly, from excitement and energetic action to withdrawal, depression, physical illness, and hostility.

There must be differences either small or vast in their way of thinking, the value system, customs and mentality etc. between the East and the West. When those people from the two different cultures encounter each other, they may feel curious about and even disgusted with each other. Under this circumstance they will mostly experience with culture shock.

Probably because of her own experience that she has gone through both in China and in the United States, Pearl Buck has a deep feeling for this kind of embarrassment and is able to describe culture shock vividly and dramatically in many of her novels such as Dragon Seed, Pavilion of Woman, and The Good Earth and so on. 


\section{A. Culture Shock in Dragon Seed}

In Dragon Seed, in order to escape from the rape and slaughter of the Japanese invaders, Ling Sao seeks shelter in a church school run by a white woman. It is the first time for Ling Sao to see such a strange woman in this strange place.

The woman had hair as yellow as cat's fur, and it did not lie smooth about her head as hair does, but it stood out like lamb's wool. The eyes in this white face were pale yellow, too, or so they looked in the light from the lantern that the woman held. (Buck, 1946:125)

In Ling Sao's mind the white woman is completely different from all the people she has seen before, but like an animal a bit. It is because Ling Sao has never seen a foreigner before and she has no idea of their appearances at all.

Later, when Ling Sao's daughter-in-law Orchid is raped and murdered by the Japanese invaders, she can't help bursting into wailing. But the white woman has no tear or a change on her face and to Ling Sao's hearty weeping she gives no more heed than if it were a child crying. The following is the dialogue between Ling Sao and the White woman.

"I think my heart will not stir again until I come into my dear Lord's presence," the white woman said.

Now it was Ling Sao who stopped weeping and because she was so astonished at the words. "But they told me you were never wed!" she cried.

"No, I am not, in the earthly way you mean," that white woman said, "but I have given myself to God, to the one true God, and one day He will take me to Him."

This she said and Ling Sao was so aghast at what she heard that her tears were dried for the time and she could only mutter, "O-mi-to-fu," to protect herself from foreign magic.

"God wants you, too, dear soul." At this Ling Sao grew most heartily afraid and she began to back away from that white woman.

"You must tell him I cannot come," she said quickly. "I have my own husband and now these two children to look after and I am a woman full of cares and I never left my own house before this." (Buck, 1946:162)

As an illiterate countrywoman, Ling Sao knows nothing about the western religion and takes for granted that the white woman and her God are both something magic and devil. In her mind, the white woman and her God has murdered Orchid and will murder her too. She is so frightened that she gives a scream and runs out. She even makes all the other women frightened at the foreign woman and God.

\section{B. Cultural Shock in The Good Earth}

Propelled by successive natural disasters, Wang Lung in The Good Earth joins the people who are flowing into the South to make a living by every possible means such as begging or pulling rickshaws. One day he occasionally meets a foreigner in his rickshaw.

"... a creature the like of whom he had never seen before. He had no idea of whether it was male or female, but it was tall and dressed in a straight black robe of some rough harsh material and there was a skin of a dead animal wrapped about his neck... Wang Lung ran as fast as he could for fear of the strange creature behind him, and when he reached the Street of Bridge he was exhausted and dripping with his sweat." (Buck, 1994: 102)

Since Wang Lung has never seen a foreigner, he will naturally regard everything different from his own as being strange, funny and unacceptable. It is just within reader's expectations that Wang Lung feels astonished and frightened at the foreigner.

During his sojourn after that time Wang Lung is confronted by a foreigner much like the one he has pulled unwittingly in his rickshaw before, but a man, very tall and lean as a tree that has been blown by bitter winds. This man has "eyes as blue as ice and a hairy face", (Buck, 1994: 116) and when he gives the paper to Wang Lung it is seen that "his hands are also hairy and red-skinned". (Ibid) He has, moreover, "a great nose projecting beyond his cheeks like a prow beyond the sides of a ship." (Ibid) Wang Lung, although frightened to take anything from his hand, is more frightened to refuse just because of his strange eyes and fearful nose. He takes what is thrust at him, and he has courage to look at it until after the foreigner has gone away.

It is a picture of a white skinned man, without clothes except for a bit about her loins, hung upon a cross-piece of wood. He seems to be dead, since his head drops upon his shoulder and eyes are closed above his bearded lips. Wang Lung is greatly baffled and horrified what he has seen.

Later that night, he gives the bizarre picture to his father, who only offers the plausible explanation: "Surely this is a very evil man to be thus hung" (Ibid, 117) It seems to be a logical inference for someone who has never before seen the Crucifixion. The Wangs associate Jesus Christ, the Savior of the world, with something evil. O-lan, for her part, has a typically utilitarian response to the matter and will even not bother to lift a finger to see what it is, having no interest in the meaning of the characters or symbols. She only knows that the heavy paper itself is rare and valuable to line the soles of a pair of shoes. The Christian message is put to "good purpose".

Therefore, either Ling Sao's or the Wangs' responses to foreigners and western religion are typical examples of culture shock because of their ignorance of intercultural contact and understanding of Western customs and religions.

\section{StRong CONFLiCT: CULTURAL CONFRONTATION}

Cultural confrontation is the sharp conflict in language and action because of different moral principles, values and systems. It will lead to the extremely antagonistic situation of the different cultures. The cultural sediment formed through long-range accumulation is not to be easily removed, and the 
cultural traditions handed down from generation to generation show great consistency and continuity. Just as Saudi Arabian women cover their faces and in America they cover very little, we cannot regard either of them to be incorrect or inferior because they are just behaving according to their own different customs. Under this circumstance we should never take a distorted view of the heterogeneous cultures. Otherwise, it will be irreconcilable between the cultures.

\section{A. Phenomenon of Culture Confrontation}

In East Wind: West Wind, Kwei-lan's parents are deeply influenced by traditional Chinese culture so both of them strongly refuse to recognize the foreign daughter-in-law.

The mother is a traditional Chinese woman. When the wire poles are erected in their old and beautiful town and also the wiring is set, the mother severely denounces it as the blaspheming against God. When she knows that message can be delivered through the ocean she says, "What can we talk with those savages? Hasn't the original God poured the seawater so as to separate us from them? It is blaspheming against God to intermingle what the God has divided." (Buck, 1998: 457) In her mind, all the actions that are not consistent with the tradition are immoral and unbearable and the foreigners are all savages. She has never expected his son's marriage with a foreign woman.

So the mother regards the interracial marriage as a dishonor and even calamity to the family. It has contaminated the sacredness of the family blood. The first time when the mother meets Mary, they both show hostility in their own eyes. Especially at the pregnancy of Mary, his mother sinks into a more distraught and indignant condition but will not acknowledge any son of the racially mixed parents as the legitimate heir of the family yet.

Kwei-lan's mother, a key character in this novel, deserves nothing. As the spokesperson of the traditional culture, she represents sagacious matrons of great families trained in the old Confucian ethics. The mother is a woman thoroughly rooted in the old ways, full of intellect of dignity. She would rather die than giving up her firm faith in old Chinese traditions and also the prestige of the family.

In fact, the confrontation of the mother and Mary just symbolizes the cultural incompatibility of the East and the West without proper mutual understanding and exchange. Any culture cannot be isolated from the other and intercultural communication is inevitable. Our civilization is a vast fabric, in which the most diverse elements are mingled, in which Nordic aggressiveness and Roman law, the new bourgeois conventions and the remnant of a Syriac religion are reconciled. In such a fabric, it is useless to look for a thread that may have remained pure and virgin without having undergone the influence of a neighboring thread. (Joyce, 1959: 165)

The mother refuses to have any contact with Mary and want to keep her cultural purity, so she has become the obstacle in the way of cultural development. Only the obstacles have been removed can the intercultural communication go on smoothly. Therefore, the death of the mother is full of meaning.

\section{B. Causes of Culture Confrontation}

Because of the different geographical conditions, historical backgrounds, progress of development and some other factors, every culture has its own characteristics.

Chinese culture is typical oriental culture and stresses the qualities of tolerance, obedience and loyalty. An important Chinese cultural value is filial piety just as the old Chinese great master states "the first duty of a man is to pay careful heed to every desire of his parents."(Confucius, 1999: 127) Thus Chinese children will feel a lifelong obligation to their parents, which is ideally exemplified by an unreserved devotion to please them in every possible way.

An individual is incorporated into the integrity of the whole. The center of the circle represents the community's interests and serves as the common objective of all its individual members. The individual exists in the community and finds the meaning of his existence through it. It is evident that the interests of the small circle (family), the intermediate circle (state), and the large circle (world) come above one's own, and one has to cultivate one's own moral character and to exert oneself in order to achieve the goal of serving the community's interests. Just as Fan Zhongyan, a poet of Song dynasty expresses his desire "to show concern over state affairs before others and enjoy comforts after them."

On the contrary, to American people, the most important value orientation is individualism. In fact, the social systems of various Western nations, and especially the United States, are based on "rugged individualism," as described by Herbert Hoover in 1928. The pursuit of individual rights and interests is considered utterly legitimate. Self-actualization and the maximal realization of individual potential are supreme aims in life. Individualism has prevailed since 19th century in the West, and it reached the peak of perfection in the 20th century with a dominant position in the field of ideology. It stresses self-determination, self-dependence and mutual respect. Individualism, different from egoism, contains ideology of democracy and freedom. They take pride in their independence and their right to make their own decisions. They go their own way, not caring much about what others might think about their doings.

The differences in their respective moral principles of the East and the West lead to their different views in marriage. Chinese people generally follow the system of "arranged marriage" while Western people choose "free love" without any interference from others. Therefore, the different views in moral principles and marriage have aroused the conflicts of the East and the West. However, if we can strengthen mutual understanding and exchange, these conflicts will be removed smoothly. On the visit to China in 1995, the famous theorist Umberto Eco said, "to know others does not mean that we should prove they are similar to us but should understand and respect their cultural differences from ours." So it's necessary for us to bear the lesson in mind that to understand one another is more important than to impose our 
belief upon other people, no matter how much better we think ours may be.

\section{CONCLUSION}

Having suffered and witnessed so much embarrassment in her own communication with heterogeneous cultures, Pearl Buck knows well enough that there are so many differences between different cultures. Therefore, cultural conflicts are unavoidable in the communication of heterogeneous cultures. Actually Pearl Buck has not denied the truth in her novels. With so many differences between heterogeneous cultures, cultural conflicts are certain to exist during the course of their mutual communication and exchange. Every culture has its own distinctive characteristics. We cannot tell which is right or which is wrong. Intercultural communication is actually a type of contact, in which cultures are confronted with ideas and information from outside sources. The native cultures are transferred to the foreign cultures and the foreign cultures are also learnt by the native cultures. Apparently, cultures are compensative to each other and are of self-perfection in the process of contact. It is wise and laudable for people of different races and countries to be conciliatory in their cultural interactions. On account of this, every one of us should be tolerant of and wide-minded to different cultures. We should perform the principle of "dialogue of civilization" and surpass the narrow conceptions of mentality, critically assimilate the essence of other cultures, and seek a dynamic balance between the relativity and universality of culture.

\section{REFERENCES}

[1] Confucius and Arthur Waley. (Trans.) The Analects, Book XII [M]. Beijing: Foreign Language Teaching and Research Press, 1999.

[2] Joyce James. The Critical Writings of James Joyce [C]. Ed. Ellsworth Mason and Richard Ellmann. New York: The Viking Press, 1959.

[3] K. Oberg, Culture Shock: Adjustments to New Cultural Environment, Practical Anthropology [M]. New York: Knopf, 1960.

[4] Pearl Buck. Dragon Seed [M]. New York: John Day, 1946.

[5] Pearl Buck. The Good Earth [M]. Great Britain: Mandarin Paperbacks, 1994.

[6] Pearl Buck. East Wind: West Wind [M]. London: Moyer Bell, 1993.

[7] Samuel P. Huntington. The Clash of Civilization and the Remarking of World [M]. London: Simon Schuster Ltd. 1987. 